\title{
A D-dimer laboratóriumi eredményeinek és klinikai értékelésének elemzése
}

\author{
Jákó János dr.
}

\begin{abstract}
A fibrinogén-fibrinmolekula enzimatikus bontásakor D-dimer is keletkezik, amelynek léte a keringésben kimutatható. A mérések alapján elfogadott határértékek egyben fiziológiásnak is tekinthetőek. Létrejöttét alvadás, majd lysis eredményének vélték. Thromboemboliás megbetegedések esetén tapasztalható vérbeli, magas koncentrációjú D-dimer diagnosztikus értékúnek tartott. Azokban az esetekben, amikor magas titer ellenére a thromboembolia kizárható, de mégis óvatosságból heparin- (LMWH-), illetve Clopidogrel-terápiát alkalmaztunk, kiderült, hogy a D-dimer értéke nem változott, magas maradt. Ez a tapasztalat azt jelenti, hogy a D-dimer kialakulásának nem előfeltétele az in vivo alvadás. Elemezve az ilyen eseteket, a háttérben májbetegséget, vesemegbetegedést találunk, de a magas kor is szerepet játszhat. Sokszor a D-dimer magas értékei mellett „párhuzamosan” a ferritinszint is emelkedett. Mindezek alapján fel kell tételeznünk egy, „elöregedett” fehérjemolekulákra vonatkoztatható enzimatikus bontási folyamatot, amely általánosan érvényes.

Orv Hetil. 2017; 158(50): 1971-1976.
\end{abstract}

Kulcsszavak: D-dimer klinikai jelentősége, fibrinogén (FBG), fibrinbomlástermék (FDP) és eliminációja

\section{Analysis of D-dimer laboratory findings and clinical evaluation}

D-dimer is a product of the enzymatic degradation of the fibrinogen-fibrin molecule, and its existence is demonstrable in circulation. The test based limits may be considered as normal values. It was first thought to be a product of coagulation, then a product of lysis. High-concentration D-dimer in blood detected in thromboembolic diseases is considered to be of diagnostic value. In cases where thromboembolism was ruled out despite elevated titres but heparin (LMWH) or CLOPIDOGREL was given as a cautionary measure, we found that D-dimer values remained elevated. This finding means that in vivo coagulation is not a precondition to D-dimer formation. Analysis of such cases uncovers liver or kidney disease in the background, but old age may also be a factor. Often elevated ferritin levels were observed 'in parallel' with elevated D-dimer values. These findings lead us to presume an enzymatic degradation process of 'elderly' protein molecules, which is universally applicable.

Keywords: D-dimer, clinical significance of D-dimer, fibrinogen (FBG), fibrin degradation product (FDP) and its elimination

Jákó J. [Analysis of D-dimer laboratory findings and clinical evaluation]. Orv Hetil. 2017; 158(50): 1971-1976.

(Beérkezett: 2017. augusztus 21.; elfogadva: 2017. szeptember 29.)

Az Orvosi Hetilap alapításának 160. évében a Szerkesztőség felkérésére készített tanulmány.

\section{Rövidítések}

DIC = diffúz intravascularis coagulatio; FBG = fibrinogén; $\mathrm{FDP}=$ (fibrin degradation product) fibrinbomlástermék; HBV = hepatitis $\mathrm{B}$-vírus; HCV = hepatitis C-vírus; $\mathrm{LMWH}=($ low molecular weight heparin) alacsony molekulatömegü heparin
A Cochrane adatbázis 2016 augusztusában közzétett jelentése a pulmonalis embolisatio igazolásának fontos laboratóriumi módszerévé nyilvánítja a D-dimer meghatározását, illetve diagnosztikus értékünek tartja annak magas koncentrációját a vérben. Ugyanakkor magának a 
laboratóriumi módszernek a szenzitivitását 80-100\% közöttire becsüli, specificitását pedig 23-63\%-nak tartja. Ebből következtetve, a negatív D-dimer-teszt-eredményt a tüdőembólia kizárására alkalmasnak véli [1].

Az FBG fibrinenzimek okozta bomlástermékeinek egyike a $\mathrm{D}$-dimer. A véralvadás I. faktora, a fibrinogén egy 340 kDa tömegű fibrilláris szerkezetű glikoprotein [2]. Három polipeptidláncból tevődik össze $(\alpha-, \beta-$, $\gamma$-lánc). Felépítését és ebből következő tulajdonságait, illetve degradációját végző proteolyticus enzimek támadáspontját krisztallográfián is alapuló technikákkal tárták fel [3].

Az FBG-molekula 46 nm hosszú, a két végén a $\beta$ - és a $\gamma$-láncok két-két nodulust alkotnak ( $\beta$-nodulus, $\gamma$-nodulus). A két végból a degradálódásnál egy-egy $\mathrm{D}$ fragmens képződik. A középső molekulaszakaszon négy bütyök helyezkedik el. Ezek illeszkednek majd a végnodulusok preformált fészkeibe. Az FBG-molekula negatív töltése biztosítja e fehérje oldatban maradását, de amikor az aktivált trombin kötődik az alfa-lánc C-régiójához, akkor bekövetkezik a lysis és ezzel egy időben elveszik a negatív töltés és az FBG kezd fibrinné alakulni azáltal, hogy megindul az end-to-end és side-to-side kapcsolódás (1. ábra) [4].

A kialakult fibrinháló plazmin hatására oldódik és úgynevezett D és E fragmentum szabadul fel, majd a D-dimer, amelynek felezési ideje négy-hat óra [5].

A D-dimer meghatározására több módszer ismeretes (1. táblázat).

A felsorolásból érzékelhető [5], hogy az eltérő mưveleti megoldások (szoftver, optika), a különböző immunszérumok (ellenanyag-tulajdonságú reagensek) alkalmazása a kapott mennyiségi eredményeket nagymértékben befolyásolják [6].
1. táblázat |A D-dimer-kimutatás módozatai [5]

\begin{tabular}{|c|c|c|}
\hline Teszt neve & Előállítója & Módszere \\
\hline D-Di Test & Diagnostica Stago M & $\begin{array}{l}\text { Latex Agglutination } \\
\text { Slide, semi-quantitative }\end{array}$ \\
\hline Acculot $^{\mathrm{TM}}$ & Sigma Diagnostics M & $\begin{array}{l}\text { Latex Agglutination, } \\
\text { semi-quantitative }\end{array}$ \\
\hline Dimertest ${ }^{\circledR}$ Latex & Dade Behring $M$ & $\begin{array}{l}\text { Latex Agglutination, } \\
\text { qualitative }\end{array}$ \\
\hline Minutex $^{\circledR}$ & Biopool M & $\begin{array}{l}\text { Latex Agglutination, } \\
\text { qualitative }\end{array}$ \\
\hline $\mathrm{MDA}^{\circledR} \mathrm{D}$-Dimer & Organon Teknika M & $\begin{array}{l}\text { Micro-Latex Immuno- } \\
\text { assay, quantitative }\end{array}$ \\
\hline AUTO D-Dimer & Sigma Diagnostics & $\begin{array}{l}\text { Automated latex } \\
\text { agglutination, } \\
\text { quantitative }\end{array}$ \\
\hline Liatest D-Dimer & Diagnostica Stago & $\begin{array}{l}\text { Micro-latex immono- } \\
\text { assay, quantitative }\end{array}$ \\
\hline Vidas DD & BioMerieux M & $\begin{array}{l}\text { Rapid ELISA, } \\
\text { quantitative }\end{array}$ \\
\hline Asserachrom $^{\circledR}$ & Diagnostica Stago & ELISA, quantitative \\
\hline $\begin{array}{l}\text { Fibronosticon } \\
\text { D-Dimer }\end{array}$ & Organon Teknica & ELISA, quantitative \\
\hline SimpliRED $^{\circledR}$ & Agen $M$ & $\begin{array}{l}\text { RBC Agglutination, } \\
\text { qualitative }\end{array}$ \\
\hline $\begin{array}{l}\text { IL-Test }^{\mathrm{TM}} \\
\text { D-Dimer }\end{array}$ & Beckman Coulter M & $\begin{array}{l}\text { Immunoturbidimetric, } \\
\text { quantitative }\end{array}$ \\
\hline $\begin{array}{l}\text { Advanced } \\
\text { D-Dimer }\end{array}$ & Dade Behring & $\begin{array}{l}\text { Immunoturbidimetric, } \\
\text { quantitative }\end{array}$ \\
\hline Miniquant & Biopool & $\begin{array}{l}\text { Immunoturbidimetric, } \\
\text { quantitative }\end{array}$ \\
\hline Innovance & Siemens BCS & Immunoturbidimetric \\
\hline Hemosit HS500 & $\begin{array}{l}\text { Instrumentation } \\
\text { Laboratory }\end{array}$ & $\begin{array}{l}\text { Automated coagulation } \\
\text { analyzer }\end{array}$ \\
\hline
\end{tabular}

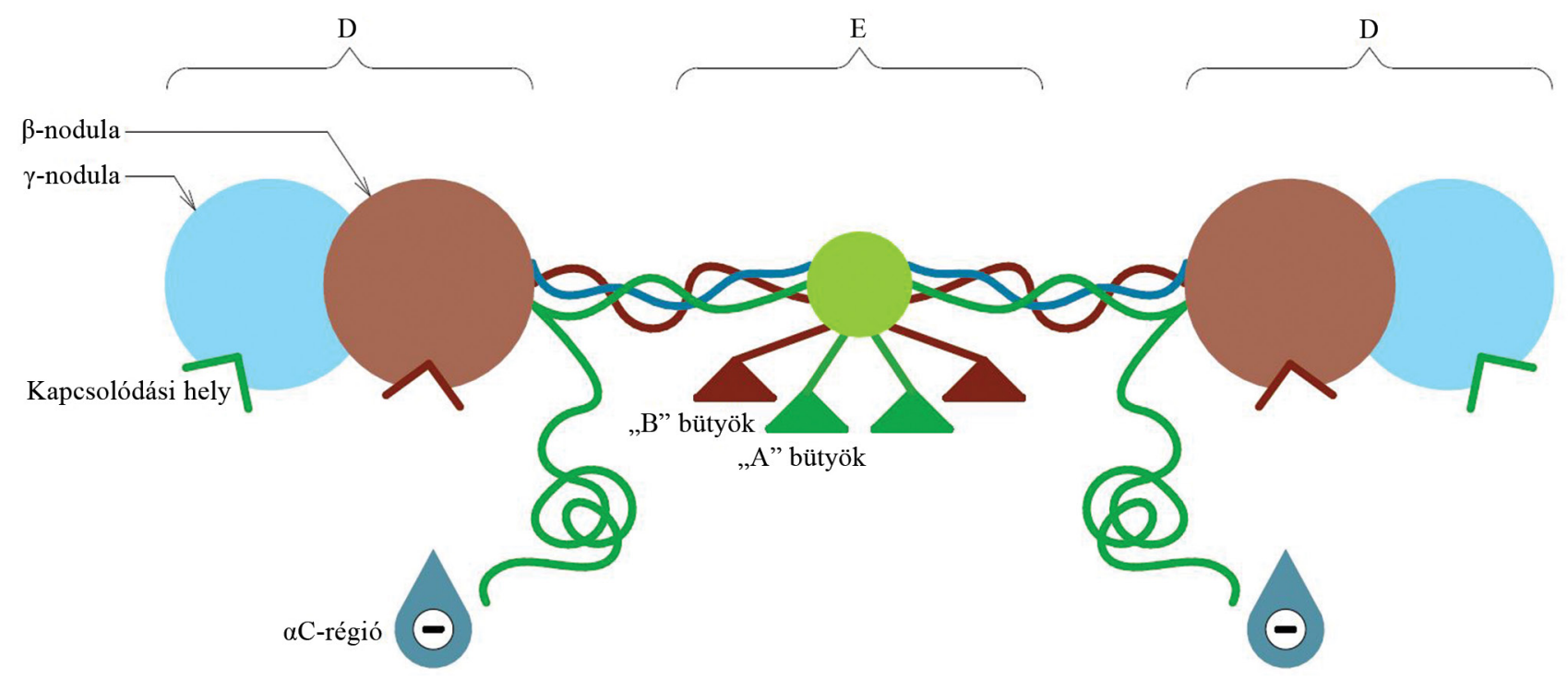

1. ábra | A fibrinogén molekula vázlatos felépítése 
A gyakorlat számára viszont szükséges a standardizáció. Általában a Diagon fejlesztette immunoturbidimetriás eljárást alkalmazzák, $\mathrm{s}$ a referenciatartományt (normális határértékek) 0-500 ngFEU/ml-ben határozzák meg. A mi vizsgálatainkban segítséget nyújtó CentrumLab Kft. Innovance elnevezésű immunoturbidimetriás technikával dolgozik.

A klinikai szakirodalomból - amelyben jól mutatja magát az eredmények biztos támpontként való értékelhetőségének nehézsége - többek között Gualtiero Palareti vizsgálatai emelhetőek ki. Több készülék, módszer vizsgálata alapján megállapította, hogy thromboemboliák eseteiben a szenzitivitása és negatív prediktív értéke 100\%. Ugyanakkor, a magas fals pozitivitása miatt, különösen 65 év felettieknél, specificitását 23-63\% közöttinek véleményezi. Következésképpen a pozitív prediktív értéke alacsony, 16-30\% közötti [7].

A hétköznapi gyakorlatban számos olyan eredménnyel találkozunk (találkoztunk), amely kóros vagy extrém kóros volta ellenére sem jelezhette a thromboembolia létét vagy patológiás alvadási folyamatot, mivel azt az elvégzett részletes, célratörő vizsgálatok teljes bizonyossággal kizárták.

Az alvadás mechanizmusával foglalkozók még ma is megosztottak, vagy elvetik, vagy elfogadják a continualis intravasalis alvadás, illetve az azt követő fibrinolysis lehetőségét.

Az a bizonytalanság, amely a vérben keringő FBG - kis százalékban bár, de - inhomogén voltának jelenlétét kísérte, vizsgálatra ösztönzött $[8,9]$.

Évek óta több kísérletet tettünk, hogy a vénás thrombosisok háttérmechanizmusában az FBG-inhomogenitást értelmezhessük.

\section{Anyag és módszer}

Kidolgoztunk egy olyan összetett módszert, amellyel az FBG, illetve degradációs terméke (FDP) kimutathatóak, továbbá mennyiségileg - ha megközelítőleg is - mérhetőek.

FBG előállítására úgynevezett precipitáló eljárást alkalmaztunk, amelynek segítségével 90-95\%-ban koagulálódó $700 \mathrm{mg} \%$-os koncentrációjú tesztoldatot állítottunk elő. A fibrinogén lysisét Actase-zal (Cilag), (0,1 ml Actase 2000 Ortho E), a lysis leállítását Trasylol-lal (Bayer) $(0,1 \mathrm{ml}$ Trasylol $500 \mathrm{KLU})$ végeztük.

Az így elóállított oldatokat (FBG, FDP) elektroszinerézissel tettük láthatóvá (2. ábra).

A D és E fragmentum FBG-ellenes ellenanyag-tartalmú gélben elektroforézis (elektroszinerézis) segítségével választható szét, mennyisége denzitometriásan mérhető. Kérdés, hogy mi a szerepe ezeknek a fragmentumoknak, illetve a sorsa.

Abban az esetben, ha feltételezzük, hogy a valószínúsített alvadás - fibrinolysis in vivo - „fiziológiás”, akkor lennie kell egy olyan clearingaktivitásnak is, amely a képződő degradációs termékeket kiszűri (3. ábra) [10].

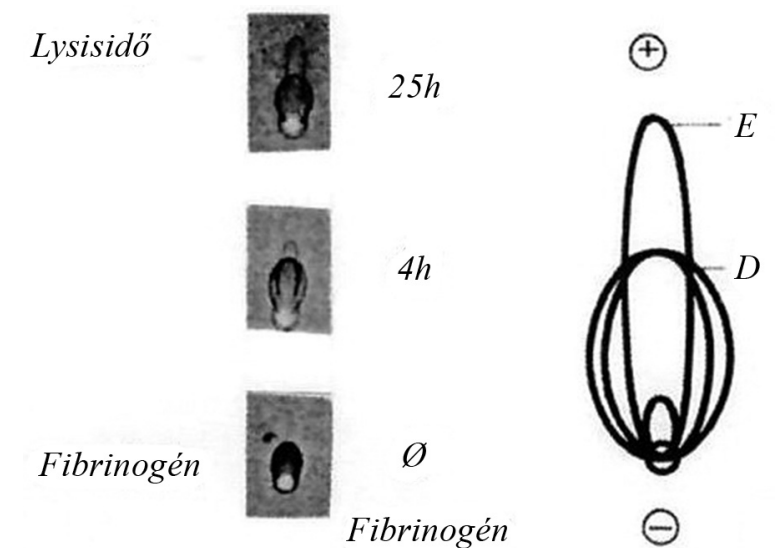

\begin{tabular}{l|l} 
2. ábra & Az FBG és FDP kimutathatósága elektroszinerézissel
\end{tabular}

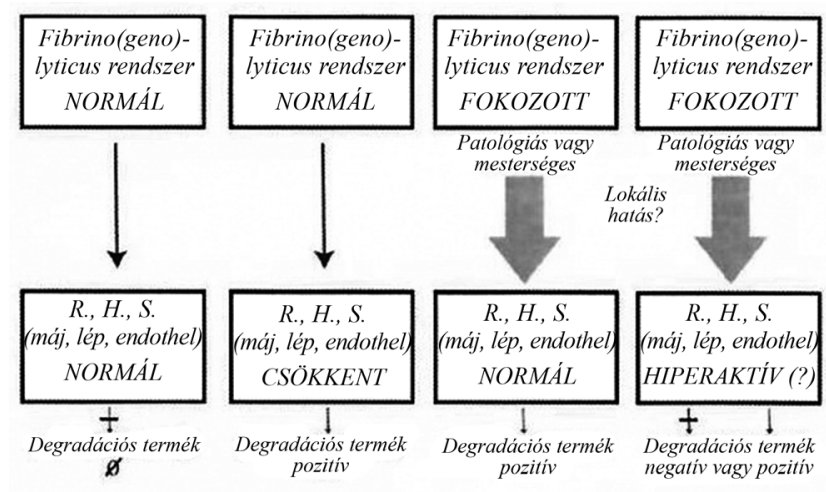

3. ábra $\mid$ Fibrino(geno)-lyticus rendszer aktiválódása és az FDP megjele nése, illetve sorsa a szervezetben

Az eliminációs út igazolására először ${ }^{125} \mathrm{~J}$-dal jelöltünk FBG-t és in vitro előállított fibrin degradációs termékeket, majd hígítási sorban az alapot jelentő azonos menynyiségú jelöletlen FBG-re és FDP-re rétegeztük és elektroszinerézist végeztünk (4. ábra).

A reprodukálható technika birtokában sikerült a két fó komponens - a D és E fragmens - lysisidőtől függő változásának vizualizálása is $[11,12]$.

Később két, 25-25 patkányból álló csoportot vizsgáltunk. Az egyik csoport ${ }^{125}$ J-izotóppal jelzett FBG-t kapott, a másik csoport 25 órás lysissel bontott FBG-t, ugyancsak ${ }^{125} \mathrm{~J}$-dal jelzettet. A patkányokat 5 -ös csoportban narkózisban laparatomizáltuk, és a közös epevezetéket kipreparálva 10 percenként gyüjtöttük az epét (5. ábra). A kicsorgó epe aktivitását mértük, majd szinerézis után a szárított preparátumot egy hétig autoradiografáltuk.

Kiderült, hogy az izotóppal jelzett FBG-t inicializálva (iv.) az állatok plazmája mutat csak aktivitást, és sem a vizeletben, sem az epében a kísérlet 2,5 órás időtartama alatt jelzett anyag nem jelent meg, ellentétben a jelölt FDP beadásánál észleltekkel. A számított és a mért aktivitási értékek nagyon pontosan egyeztek és biológiai kísérletben jónak mondhatóak (6. és 7. ábra). 


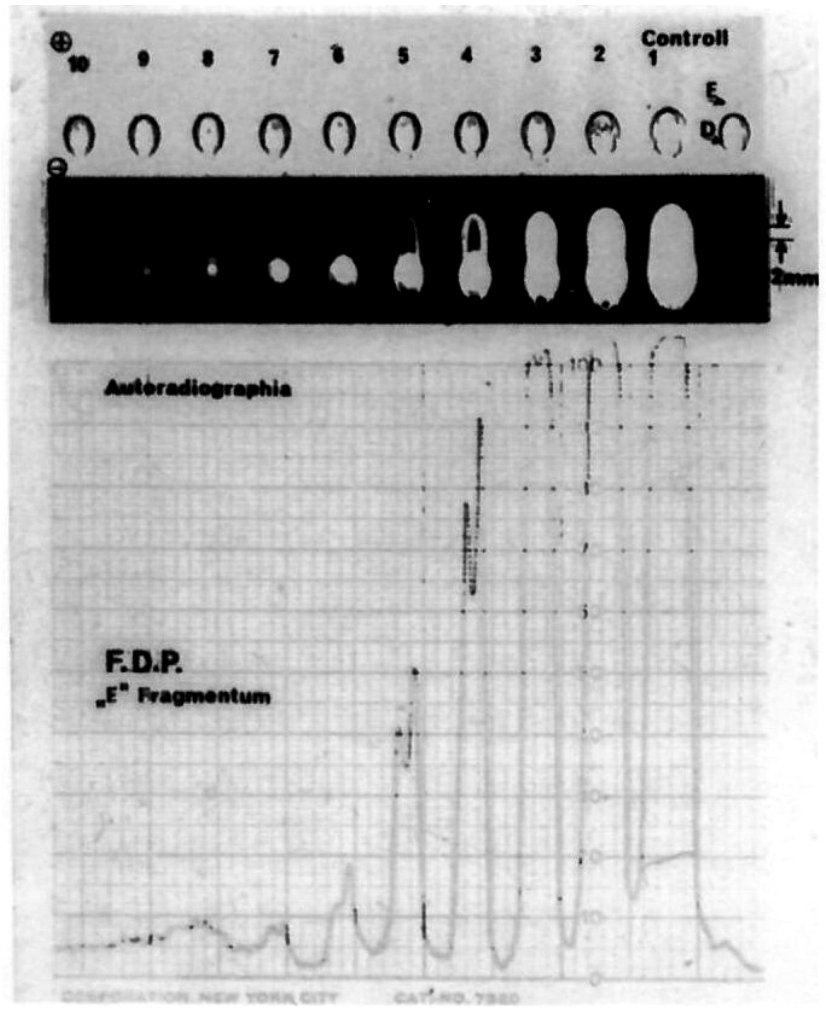

4. ábra | Elektroszinerézis és autoradiográfia

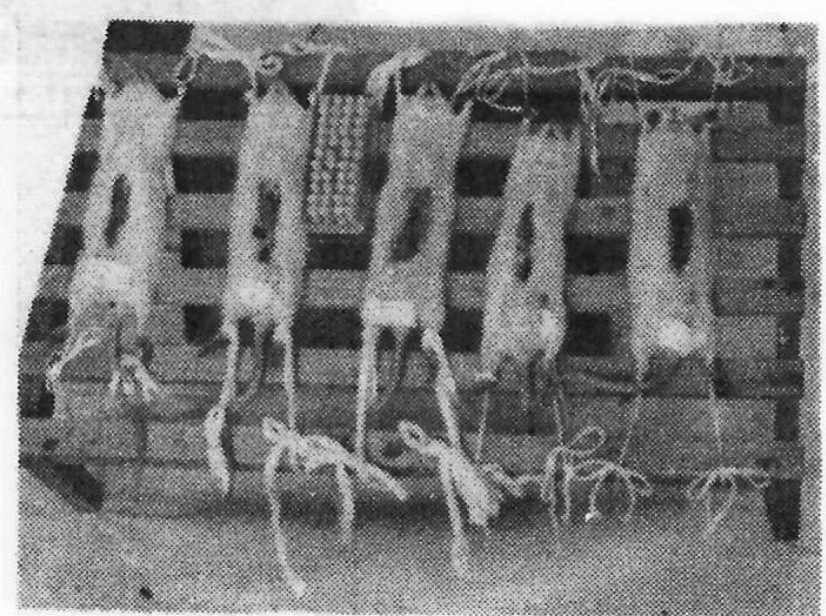

5. ábra

\begin{tabular}{|llll}
\hline & \multicolumn{4}{l}{ A patkányok epéjének gyújtése } \\
\hline I. & 25 & Beadlatok száma & Dozírozás \\
\hline II. & 25 & Iv $93 \mu \mathrm{Ci} \mathrm{FBG}{ }^{125} \mathrm{~J}$ & $1 \mathrm{ml} /$ állat \\
\end{tabular}

A patkányok súlyából számított plazmamennyiség általában $\sim 11,016 \mathrm{ml}, 3 \mu \mathrm{l}$ aktivitása $8,75 \times 10^{-4} \mu \mathrm{Ci}$, plazma-összaktivitása 3,21 $\mu \mathrm{Ci}$. Az epében kiválasztott összaktivitás 69,19 $\mathrm{MCi}$.

A beadott $93 \mu \mathrm{Ci}$ és a beadás utáni plazma-, illetve epeaktivitás összesen $72,4 \mu \mathrm{Ci}$, amely differencia elfo-

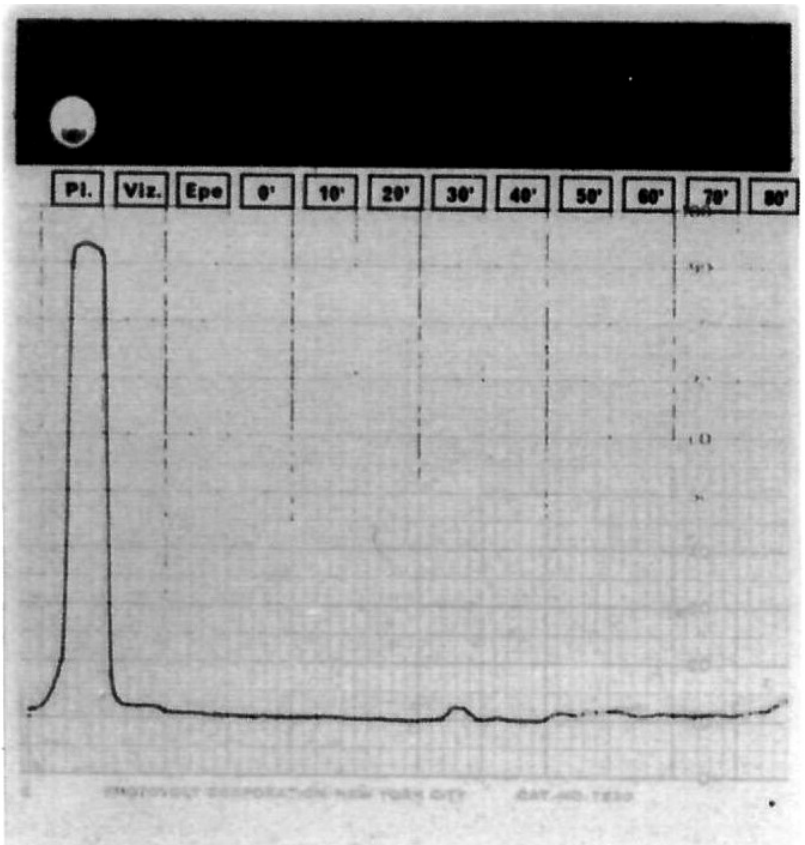

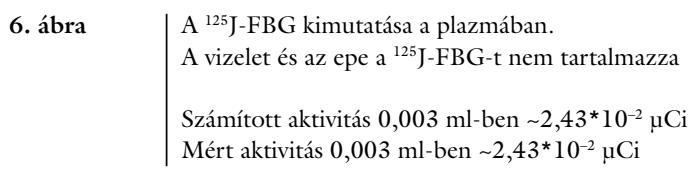
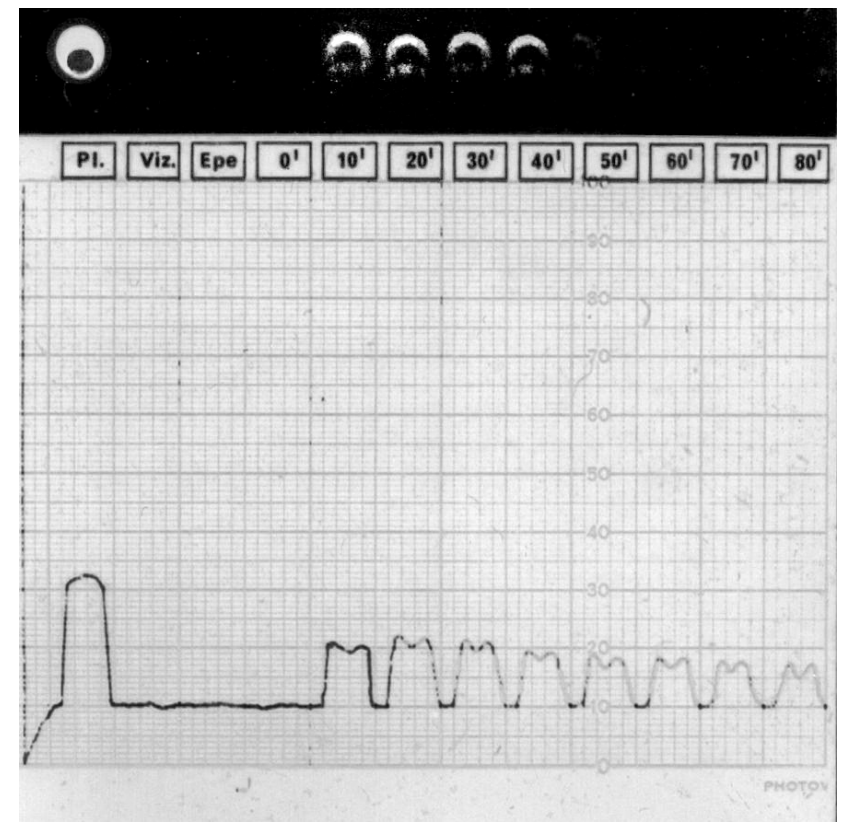

7. ábra

A ${ }^{125}$ J-FDP megjelenése az epében, de közvetlenül az inicializá lás után a plazmában is kimutatható, de a vizeletben nem

gadható, ha a macrophagokban és Kupfer-sejtekben lévő anyag mennyiségét figyelembe vehetjük.

A szövettani metszetek autoradiográfiája is egyértelmúen bizonyította az eloszlás és az elimináció tényét ( 8 . és 9. ábra) [13]. 


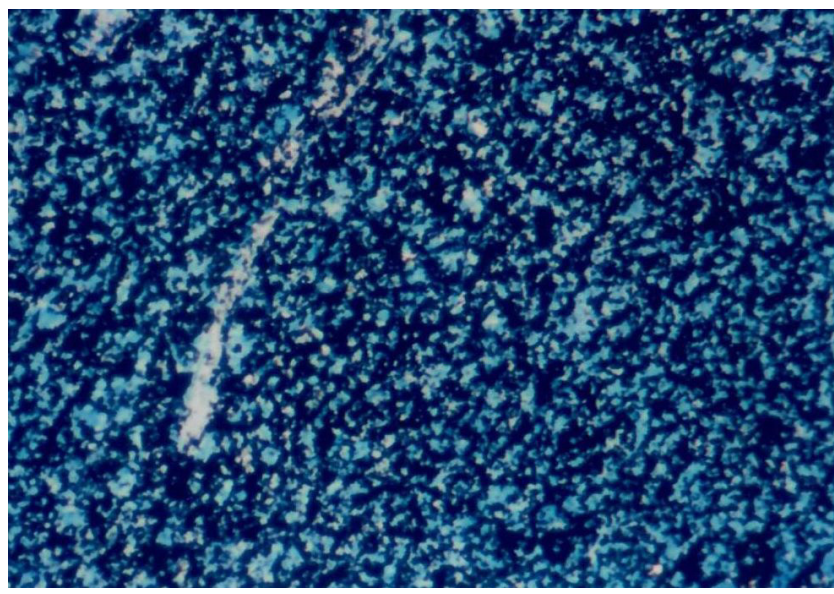

8. ábra

A ${ }^{125} \mathrm{~J}$-dal jelzett FBG-t kapott patkány mája, mutatva a homogén eloszlást

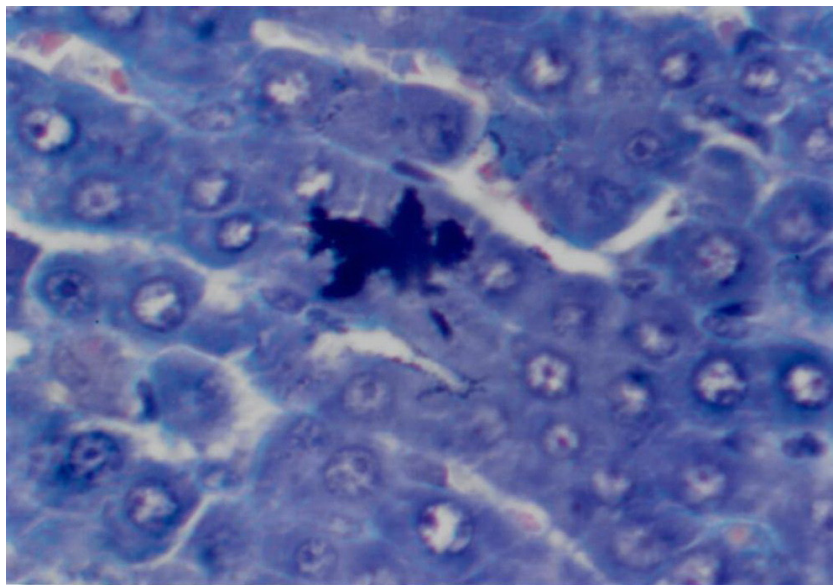

9. ábra

A ${ }^{125} \mathrm{~J}$-dal jelzett FBG-vel kezelt patkány májában csak a Kupfersejtben van aktivitás

\section{Eredmények}

Az említett vizsgálatok alapján egyértelmú, hogy az FBG-ből származó, a keringésben kimutatható D-dimer molekula a bélcsatornába távozik s másodlagos digestiónak esik áldozatául.

Felvetődött azonban a kérdés, hogy ha klinikailag az intravasalis alvadás biztonsággal kizárható, tehát a thromboembolia nem vetődik fel, akkor honnan kerül a keringésbe a laboratóriumilag kétséget kizáróan igazolható D-dimer-molekula. A kérdés fontossága annál is inkább nyugtalanító, mivel számos olyan beteget észleltünk, akinek D-dimer-értéke a normális felső határ 2-3-szorosa.

\section{Klinikai vizsgálatok}

2016. januártól 2017 márciusáig 120 D-dimer-meghatározásra szóló igény érkezett a labratóriumba. Ezek közül 67 esetben igazolódott $500 \mathrm{ngFEU} / \mathrm{ml}$ feletti érték (2. táblázat).
2. táblázat A válogatás nélküli beteganyag D-dimer-vizsgálati eredményeinek megoszlása

\begin{tabular}{lccc}
\hline \multirow{2}{*}{$\begin{array}{c}\text { D-dimer } \\
(\mathrm{ngFEU} / \mathrm{ml})\end{array}$} & $\begin{array}{c}\text { Esetek } \\
\text { száma }\end{array}$ & \multicolumn{2}{c}{ Életkor (év) } \\
\cline { 3 - 4 } $500-1000$ & 25 & átlag & tartomány \\
$1000-1500$ & 23 & 64,6 & $27-86$ \\
$1500-2000$ & 10 & 66,3 & $27-87$ \\
$2500-3000$ & 6 & 72,4 & $42-83$ \\
$>3000$ & 3 & 72,8 & $36-70$ \\
\hline
\end{tabular}

A részletes vizsgálatok 66 betegnél a vénás thrombosis lehetőségét elvetették. Alvadásra utaló tünet 53 negatív (normális) esetben sem volt kóros.

A D-dimer kóros titerú jelenlétét a keringésben a következőkben foglalták össze [14]:

- DIC,

- fibrinolyticus kezelés után,

- thromboembolia kíséretében,

- pulmonalis embolia, embolisatio esetében,

- mélyvénás thrombosisnál,

- akut myocardialis infarctus (24-48 óra között),

- praeeclampsia klinikai állapotában,

- nagyobb fizikai megterhelés, stressz,

- májbetegség,

- akut végtagischaemia,

- akut cardiovascularis történés,

- akut és krónikus vesekárosodás (glomerulonephritis),

- szepszis, sokk,

- posztoperatív állapot,

- extenzív szövetkárosodás (politraumatizáció).

Azok közül a betegek közül, akik a felsorolt - irodalomban található - lehetőségek egyikébe sem voltak besorolhatók, de ugyanakkor felvetődött a thrombusképződés esetlegessége, öt beteget kiválasztottunk és 80-100 napig LMWH-val, illetve Clopidogrellel kezeltük (3. táblázat).

3. táblázat $\mid$ Az antikoagulánsok D-dimer koncentrációjára kifejtett hatástalanságának bemutatása

\begin{tabular}{lcc}
\hline Alvadásgátló & Vérvétel ideje & $\begin{array}{c}\text { D-dimer } \\
(\mathrm{ngFEU} / \mathrm{ml})\end{array}$ \\
\hline Clexane & 2015.04 .22 & 963 \\
$4000 \mathrm{NE} /$ nap & 2015.04 .27 & 1432 \\
& 2015.05 .04 & 806 \\
$\sim 80 \mathrm{nap}$ & 2015.06 .17 & 1244 \\
\hline Clopidogrel & 2015.09 .02 & 1169 \\
$75 \mathrm{mg} /$ nap & 2015.10 .07 & 1206 \\
& 2015.11 .11 & 1362 \\
$\sim 100 \mathrm{nap}$ & 2015.12 .16 & 962 \\
\hline
\end{tabular}

Az előzőekben tapasztalt magas D-dimer-titer azonban gyakorlatilag az alvadásgátlók hatására sem változott, jelezve azt, hogy az intravasalis FDP létrejöttét a legnagyobb valószínúséggel nem előzi meg alvadás, ha- 
nem valószínúleg intracellulárisan proteolyticus enzimek hatására következik be az „elöregedett”(?) FBG-molekulák bontása.

\section{Megbeszélés}

Nyilvánvaló, hogy az irodalomban található felsorolás nem egységes kórlényeget takar, hiszen a kóros (DIC) vagy mesterséges fibrinolysis következménye nem sorolható a thromboemboliák okozta megbetegedésekhez. A szövetkárosodással járó állapotok (posztoperatív státusz vagy traumatizáció) sem hasonlíthatóak a máj- vagy vesebetegségekhez, annak ellenére sem, hogy az utóbbiaknál is van szövetkárosodás, sőt elhalás is, de a mértékek nem azonosak. Tény azonban, hogy a thromboemboliák nyomon követése, helyesebben gyógyítása esetén a D-dimer koncentrációja csökkenő tendenciát mutat és normalizálódik. (Különösen thromboemboliás fiatalabb betegek gyógyulásánál látjuk ezt törvényszerűen.) Fontos még egyszer annak hangsúlyozása, hogy normális Ddimer-érték a thromboembolia létét szinte biztonsággal kizárja [15, 16].

\section{Következtetés}

Vizsgálataink szerint a legnagyobb valószínúséggel fiziológiás körülmények között intravasalis alvadás nincsen. Az FDP jelenléte nem csak alvadás utáni fibrinolysis eredménye. A hétköznapi gyakorlatban intravasalis alvadás (thromboembolia) nélküli magas D-dimer-értéket észlelünk májbetegségek (HBV-, HCV-vírus-hordozóknál), idült vesebetegségek esetén [17, 18]. Következésképpen felvetődik itt annak a lehetősége, hogy a degradálódott molekulák eltávolítása is akadályba ütközhet a máj ilyen irányú múködésének csökkenése miatt. Tapasztaltuk továbbá, hogy a magas $\mathrm{D}$-dimer-titer többször, negatív májfunkciós próbák mellett magas ferritinértékhez is csatlakozhat. Közelebbről vizsgálva a ferritin és D-dimer öszszefüggését - ha van egyáltalán -, ma még enigma [16]. Bár ismert az a tapasztalat, hogy az alkoholizmusban is emelkedett lehet a ferritin és a D-dimer is [19].

További vizsgálatokra és szorgos megfigyelésre van szükség, hogy az említett tapasztalatok igazolást nyerjenek.

Anyagi támogatás: A közlemény megírása anyagi támogatásban nem részesült.

A cikk végleges változatát a szerző elolvasta és jóváhagyta.

Érdekeltségek: A szerzőnek nincsenek érdekeltségei.

\section{Köszönetnyilvánítás}

Köszönetemet fejezem ki együttmúködéséért a Centrum-Lab Laboratóriumi Diagnosztikai Kft.-nek.

\section{Irodalom}

[1] Crawford F, Andras A, Welch K, et al. D-dimer test for excluding the diagnosis of pulmonary embolism. Cochrane Database Syst Rev. 2016; (8): CD010864.

[2] Lord ST. Fibrinogen and fibrin: scaffold proteins in hemostasis. Curr Opin Hematol. 2007; 14: 236-241.

[3] Kollman JM, Pandi L, Sawaya MR, et al. Crystal structure of human fibrinogen. Biochemistry 2009; 48: 3877-3886.

[4] Tsurupa G, Pechik I, Litvinov RI, et al. On the mechanism of $\alpha \mathrm{C}$ polymer formation in fibrin. Biochemistry 2012; 51: 25262538.

[5] Schreiber DH. The role of D-dimer in the diagnosis of venous thromboembolism. Lab Med. 2002; 33: 136-141.

[6] Legnani C, Cini M, Scarvelis D, et al. Multicenter evaluation of a new quantitative highly sensitive $\mathrm{D}$-dimer assay, the Hemosil ${ }^{\circledR}$ D-dimer HS 500, in patients with clinically suspected venous thromboembolism. Thromb Res. 2010; 125: 398-401.

[7] Palareti G, Legnani C, Cosmi B, et al. Predictive value of D dimer test for reccurent venous thromboembolism after anticoagulation withdrawal in subjects with a previous idiopathic event and in carriers of congenital thrombophilia. Circulation 2003; 108: 313-318.

[8] Fiam B, Jákó J. Immuno-electrophoresis examination of fibrinogen and labile fibrinogen. [A fibrinogen és labilis fibrinogen immunelektrophoresises vizsgálata.] Honvédorvos 1966; 18: 298303. [Hungarian]

[9] Jákó J, Sas G, Pádár J. Assay of fibrinogen by gel diffusion. [A fibrinogen mennyiségi meghatározása géldiffusios módszerrel.] Rheumatológia, Balneológia, Allergológia 1968; 9: 165-172. [Hungarian]

[10] Jákó J, Sas G. Das Fibrinogen, die Fibrindegradationsprodukte und ihr chemischer Nachweis. Haematologia 1970; (Suppl 1): $105-113$.

[11] Sas G, Jákó J, Domán J, et al. A rapid method for the semiquantitative determination of fibrinogen and fibrinogen degradation products (FDP) in defibrination syndrome. Thromb Diath Haemorrh. 1971; 25: 555-565.

[12] Sas G, Blaskó G, Jákó J, et al. Inhibitory effect of "late" type fibrinogen degradation products (FDP), upon the ethanol gelation of plasma. Haematologia 1973; 7: 369-374.

[13] Jákó J, Sebő́k J. Experimentelle Angaben über den Eliminationsweg der Degradations produkte von Fibrinogen/Fibrin. Immunhaematologie 1979; 6: 225-228.

[14] Authors' names not included. Fibrinogen: split products. N Engl J Med. 1968; 278: 793-794.

[15] Van der Graaf F, van den Borne H, van der Kolk M, et al. Exlusion of deep venous thrombosis with $\mathrm{D}$-dimer testing comparison of $13 \mathrm{D}$-dimer methods in 99 outpatients suspected of deep venous thrombosis using venography as reference standard. Thromb Haemost. 2000; 83: 191-198.

[16] Reber G, de Moerloose P. D-dimer assays for the exclusion of venous thromboembolism. Sem Thromb Hemost. 2000; 26: 619-624.

[17] Dhanunjaya Y, Usha Anand, Anand CV. A study of plasma D dimer levels in various stages of liver disease. J Liver 2013; 2: 119. doi: 10.4172/2167-0889.1000119

[18] Gordge MP, Faint RW, Rylance PB, et al. Plasma D-dimer: a useful marker of fibrin breakdown in renal failure. Thromb Haemost. 1989; 61: 522-525.

[19] Wang W, Knovich MA, Coffman LG, et al. Serum ferritin: Past, present and future. Biochim Biophys Acta 2010; 1800: 760769.

(Jákó János dr., Budapest, Oltvány u. 28., 1112 e-mail: dr.jako.janos@gmail.com) 